\title{
Streptococcus plurextorum sp. nov., isolated from pigs
}

\author{
A. I. Vela, A. Casamayor, V. Sánchez del Rey, L. Domínguez \\ and J. F. Fernández-Garayzábal
}

Correspondence

J. F. Fernández-Garayzábal garayzab@vet.ucm.es

\author{
Laboratorio de Vigilancia Sanitaria Veterinaria (VISAVET), Departamento de Sanidad Animal, \\ Facultad de Veterinaria, Universidad Complutense, 28040 Madrid, Spain
}

\begin{abstract}
Biochemical and molecular genetic studies were performed on an unknown Gram-positive, catalase-negative, coccus-shaped organism isolated from clinical samples from pigs. On the basis of the results of cellular morphological and biochemical tests, the organism was identified as a streptococcal species. 16S rRNA gene sequence comparisons confirmed its identification as a member of the genus Streptococcus, but the organism was distinct from any recognized species of this genus. The closest phylogenetic relative of the unknown organism corresponded to Streptococcus suis NCTC $10234^{\top}$ (97.2\% 16S rRNA gene sequence similarity) and this phylogenetic position was confirmed by analysis of $r p o B$ and $\operatorname{sod} A$ sequences. DNA-DNA hybridization studies showed that the unidentified organism produced a DNA reassociation value of $36.6 \%$ with respect to $S$. suis NCTC $10234^{\top}$. The novel bacterium was distinguished from $S$. suis and other Streptococcus species using biochemical tests. On the basis of phenotypic and phylogenetic data, the unidentified organism represents a novel species of the genus Streptococcus, for which the name Streptococcus plurextorum sp. nov. is proposed. The type strain is $1956-02^{\top}\left(=\right.$ CECT $7308^{\top}=$ CCUG $\left.52972^{\top}\right)$.
\end{abstract}

Although streptococci can be isolated as part of the normal flora of the skin, alimentary, respiratory and genitourinary tracts of humans and various animals (Kilian, 1998), some species are well-established as pathogens that cause a variety of diseases such as endometritis, respiratory infections, endocarditis, meningitis, arthritis and mastitis (Chanter, 1997; Köhler, 2007). In recent years, novel streptococcal species isolated from animals have been described (Lawson et al., 2005a, b; Collins et al., 2001, 2002; Vela et al., 2002). In this article, we report the phenotypic and phylogenetic characterization of two strains of an unusual Streptococcus-like organism isolated from clinical specimens from pigs. On the basis of the data presented, a novel species of the genus Streptococcus is described.

Bacterial strains were isolated in 2002 and 2003 from the lung (strain 1956-02 ${ }^{\mathrm{T}}$ ) and kidney (strain 1355-03) of two pigs with lesions associated with pneumonia and septicaemia, respectively. The pigs were kept under intensive-

The GenBank/EMBL/DDBJ accession numbers for the 16S rRNA, rpo $B$ and sod $A$ gene sequences of strain $1956-02^{\top}$ are AM774228, AM774232 and AM774230, respectively; those for strain 1355-03 are AM774229, AM774233 and AM774231, respectively.

A complete neighbour-joining phylogenetic tree, based on 16S rRNA gene sequences, showing the position of strain CECT $7308^{\top}$ with respect to Streptococcus reference species, is available with the online version of this paper. management conditions at different farms. Strains were isolated on Columbia blood agar plates (bioMérieux) incubated for $24 \mathrm{~h}$ at $37{ }^{\circ} \mathrm{C}$ under both aerobic and anaerobic [with 4-10\% $\mathrm{CO}_{2}$; GasPak Plus (BBL) system] conditions.

The novel isolates were Gram-stained and assessed for the presence of catalase. The haemolytic reaction was assessed on Columbia agar containing $5 \%$ defibrinated sheep blood (bioMérieux) incubated aerobically at $37{ }^{\circ} \mathrm{C}$ for 24 and $48 \mathrm{~h}$ (Facklam \& Elliot, 1995). Growth was determined, as recommended by Facklam \& Elliot (1995), at 10 and $42{ }^{\circ} \mathrm{C}$ in brain heart infusion broth (Difco) supplemented with 3, 4.5 and $6.5 \% \mathrm{NaCl}$, with the $\mathrm{pH}$ adjusted to 7.5. Growth in brain heart infusion broth at $\mathrm{pH} 9.6$ was assessed (Facklam \& Elliot, 1995). Susceptibility to optochin was determined using commercial (Oxoid) discs as described previously (Ruoff et al., 2003). The Lancefield serological group reaction was determined with the commercial Slidex Streptokit according to the manufacturer's instructions (bioMérieux). The isolates were characterized biochemically using the API Rapid ID 32 Strep, API ZYM and API $50 \mathrm{CH}$ systems (all bioMérieux) according to the manufacturer's instructions. The API $50 \mathrm{CH}$ strips (with $\mathrm{CHB}$ suspension medium) were read after incubation for up to 7 days at $37{ }^{\circ} \mathrm{C}$. With the API Rapid ID 32 Strep kit, the phenotypic profiles of the isolates were identical (43072401100) and corresponded to a presumptive 
identification as Streptococcus pneumoniae. However, this species could be differentiated from the novel pig isolates by its ability to produce acid from amygdalin (Kilian, 1998) and by its susceptibility to optochin (Facklam, 2002). Moreover, the novel coccus-shaped organism gave a positive reaction for Lancefield group B antisera. A detailed description of the physiological, biochemical and morphological characteristics of the isolates is given in the species description and in Table 1.

A phylogenetic analysis was performed on the basis of $16 \mathrm{~S}$ rRNA gene sequence comparisons, as described previously (Vela et al., 2002). A large fragment (approx. 1450 bases) of the 16S rRNA gene of both novel isolates was obtained bidirectionally. The $16 \mathrm{~S}$ rRNA gene sequence analysis revealed $99.6 \%$ similarity between the two strains, thereby demonstrating strong genealogical similarity. Sequence searches of GenBank using the FASTA program (Pearson, 1994) revealed that the unknown cocci were phylogenetically most closely related to Streptococcus suis NCTC $10234^{\mathrm{T}}$ $(97.2 \%$ 16S rRNA gene sequence similarity). These sequences and those of other representative species within the genus Streptococcus were retrieved from GenBank and aligned with the newly determined sequence by using the program dnaTools (Rasmussen, 1995). Phylogenetic trees were constructed using three different methods: a neighbourjoining algorithm (Saitou \& Nei, 1987), performed with the programs dnaTools and TreeView (Page, 1996); maximumlikelihood analysis performed using PHYML software (Guindon \& Gascuel, 2003); and a maximum-parsimony method carried out using the MEGA software package, version 3.1 (Kumar et al., 2004). Genetic distances for the neighbourjoining and maximum-likelihood algorithms were calculated using the Kimura two-parameter model (Kimura, 1980), whereas the maximum-parsimony analysis was performed using the close-neighbour-interchange search option (search level $=2$, random additions $=100$ ). The stability of the groupings was estimated by means of bootstrap analysis (based on 1000 replications). The phylogenetic trees obtained using neighbour-joining (Fig. 1; an extended version of this tree is presented in Supplementary Fig. S1, available in IJSEM Online) and the other two methods (data not shown) revealed a clear affiliation between the unidentified cocci (as exemplified by strain 1956-02 ${ }^{\mathrm{T}}$ ) and the genus Streptococcus. Strain $1956-02^{\mathrm{T}}$ formed a distinct subline, clustering within a small subgroup of species (embracing S. suis, Streptococcus entericus and Streptococcus acidominimus), but bootstrap resampling analysis did not demonstrate a strong association between strain $1956-02^{\mathrm{T}}$ and the aforementioned species. However, the branching position of strain $1956-02^{\mathrm{T}}$ with respect to its closest phylogenetic relative, $S$. suis NCTC $10234^{\mathrm{T}}$, was relatively stable, according to the three treemaking algorithms used in this study (Fig. 1). The unidentified isolates were distinguished from $S$. suis on the basis of phenotypic data (Table 1) and the negative results obtained using a S. suis-specific PCR-based assay that targets the glutamate dehydrogenase $(g d h)$ gene (Okwumabua et al., 2003).
Table 1. Characteristics useful in differentiating strain 1956$02^{\top}$ from closely related species of the genus Streptococcus

Strains: $1,1956-02^{\mathrm{T}} ; 2$, S. suis CCUG $7984^{\mathrm{T}} ; 3$, S. entericus CECT $5353^{\mathrm{T}}$; 4, S. acidominimus CCUG $27296^{\mathrm{T}}$. Data for Streptococcus species are taken from this study. + , Positive reaction, - , negative reaction.

\begin{tabular}{|c|c|c|c|c|}
\hline Characteristic & 1 & 2 & 3 & 4 \\
\hline \multicolumn{5}{|l|}{ Hydrolysis of:* } \\
\hline Arginine & - & + & - & - \\
\hline Hippurate & - & - & - & $+\dagger$ \\
\hline \multicolumn{5}{|l|}{ Production of: ${ }^{*}$} \\
\hline$\beta$-Glucosidase & - & + & + & $+\ddagger$ \\
\hline$\alpha$-Galactosidase & + & + & - & - \\
\hline$\beta$-Glucuronidase & + & + & - & $-\S$ \\
\hline Pyroglutamic acid arylamidase & - & + & - & + \\
\hline \multicolumn{5}{|l|}{ Production of acid from: ${ }^{*}$} \\
\hline Mannitol & - & - & - & + \\
\hline Raffinose & + & + & - & - \\
\hline Cyclodextrin & - & - & + & - \\
\hline Glycogen & - & + & + & - \\
\hline Methyl $\beta$-D-glucopyranoside & - & + & + & - \\
\hline Pullulan & - & + & - & - \\
\hline \multicolumn{5}{|l|}{ Production of:II } \\
\hline$\alpha$-Glucosidase & - & + & - & + \\
\hline Esterase $(\mathrm{C} 4)$ & - & + & + & - \\
\hline Ester lipase (C8) & - & + & + & - \\
\hline$\alpha$-Chymotrypsin & - & - & - & + \\
\hline Acid phosphatase & + & - & + & + \\
\hline $\begin{array}{l}\text { Naphthol-AS-BI-phosphohy- } \\
\text { drolase }\end{array}$ & - & - & + & - \\
\hline \multicolumn{5}{|l|}{ Production of acid from: 9} \\
\hline Mannose & - & + & + & + \\
\hline$N$-Acetylglucosamine & - & + & + & + \\
\hline Arbutin & - & - & + & - \\
\hline Cellobiose & - & + & + & - \\
\hline Aesculin & - & + & + & + \\
\hline Inulin & - & + & - & - \\
\hline Salicin & + & + & + & - \\
\hline Starch & - & + & + & - \\
\hline Gentiobiose & - & - & + & - \\
\hline Fructose & + & + & + & - \\
\hline Lancefield antigen & B & $\mathrm{D}$ & $\mathrm{D}$ & $\mathrm{D}$ \\
\hline
\end{tabular}

${ }^{\star}$ Results obtained using the API Rapid ID 32 Strep kit. $\dagger$ Negative reaction according to Devriese et al. (1999). ¥Negative reaction according to Collins et al. (2002). §Positive reaction according to Devriese et al. (1999). IIResults obtained using the API ZYM kit.

SResults obtained using the API $50 \mathrm{CH}$ kit.

Additional gene sequence analyses were performed in order to clarify the phylogenetic affinities of the two novel isolates. Partial sequences of the $r p o B(701 \mathrm{bp})$ and $\operatorname{sod} A$ (356 bp) genes were amplified and sequenced as described previously (Poyart et al., 1998; Drancourt et al., 2004). Evolutionary distances were calculated using the Kimura two-parameter model (Kimura, 1980) and the resulting 


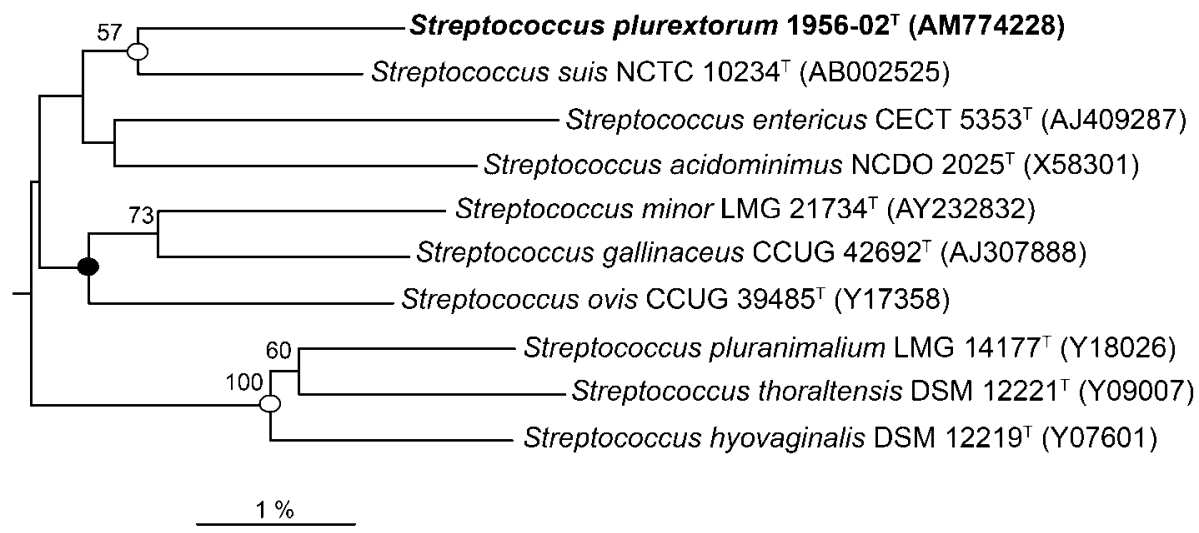

Fig. 1. Neighbour-joining phylogenetic tree, based on 16S rRNA gene sequences, showing the relationships between strain $1956-02^{\top}$ and species of the genus Streptococcus. Bootstrap percentages (based on 1000 replications) $>50 \%$ are shown at branching points. Open circles indicate that the corresponding nodes (groupings) were also obtained in the maximum-likelihood and parsimony trees. The filled circle indicates that the corresponding node was also obtained in maximum-parsimony trees. Enterococcus faecalis ATCC $19433^{\top}$ (not shown) was used as an outgroup. Bar, $1 \%$ sequence divergence. A full version of this tree is presented in Supplementary Fig. S1 (available with IJSEM Online).

trees were constructed using the neighbour-joining method (Saitou \& Nei, 1987). Bootstrap percentages (based on 1000 replicates) were also calculated. Strains $1956-02^{\mathrm{T}}$ and 1355-03 shared high levels of sequence similarity with each other: $95.8 \%$ for the sodA gene and $98.9 \%$ for the $r p o B$ gene. With regard to related strains, $1956-02^{\mathrm{T}}$ and $1355-03$ showed the highest similarities with sequences from S. suis ATCC $43765^{\mathrm{T}}$ : 85.4-85.8\% for sodA and $85.1-85.2 \%$ for rpoB. Strain $1956-02^{\mathrm{T}}$ formed a separate branch with respect to $S$. suis and other Streptococcus species in the phylogenetic tree inferred from the sodA (Fig. 2) and $r p o B$ (data not shown) gene sequence comparisons.

DNA-DNA hybridization experiments were carried out between the two isolates (strains $1956-02^{\mathrm{T}}$ and $1355-03$ ) and between strain $1956-02^{\mathrm{T}}$ and its closest phylogenetic neighbour, S. suis NCTC $10234^{\mathrm{T}}$. Genomic DNA was isolated using a French pressure cell (Thermo Spectronic) and was purified by means of chromatography on hydroxyapatite as described by Cashion et al. (1977). DNA-DNA hybridization was performed in $2 \times$ SSC at $68{ }^{\circ} \mathrm{C}$ by the Identification Service of the Deutsche Sammlung von Mikroorganismen und Zellkulturen (Braunschweig, Germany) using the method described by De Ley et al. (1970) and the modifications described by Huß et al. (1983). A Cary 100 Bio UV/VIS spectrophotometer equipped with a Peltier-thermostatted $6 \times 6$ multicell changer was used along with a temperature controller with an in situ temperature probe (Varian). DNA-DNA hybridization between the two novel isolates demonstrated $81.6 \%$ DNA relatedness, showing that they are members of the same species (Wayne et al., 1987). The DNA-DNA reassociation value between strain $1956-02^{\mathrm{T}}$ and $S$. suis NCTC $10234^{\mathrm{T}}$ was $36.6 \%$, clearly confirming that the novel isolates constitute a separate species (Wayne et al., 1987).

The $\mathrm{G}+\mathrm{C}$ content of the DNA of a representative isolate (strain $1956-02^{\mathrm{T}}$ ) was determined at the Deutsche

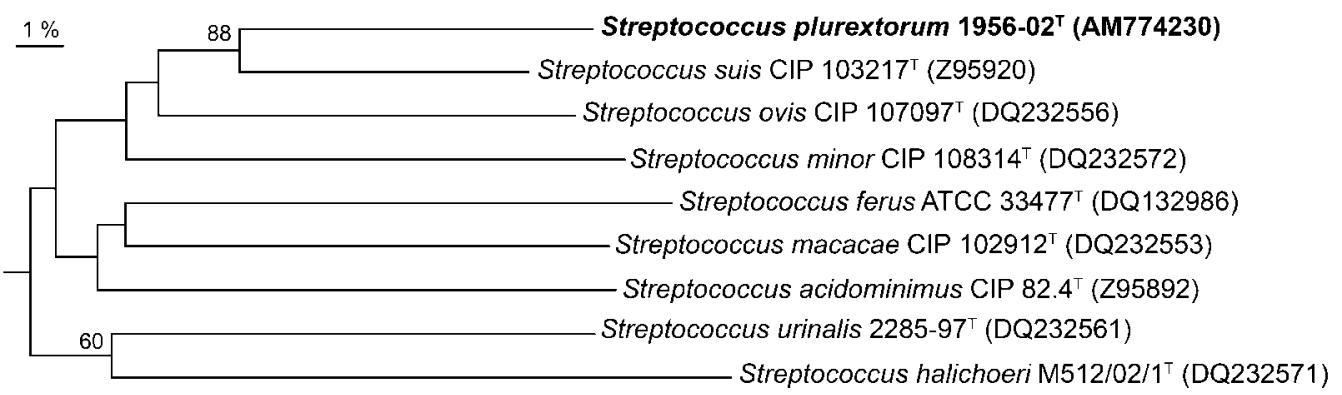

Fig. 2. Phylogenetic tree, based on sodA gene-fragment sequences, showing the relationships between strain $1956-02^{\top}$ and species of the genus Streptococcus. Bootstrap percentages (based on 1000 replications) $>50 \%$ are shown at branching points. E. faecalis ATCC $19433^{\top}$ (not shown) was used as an outgroup. Bar, $1 \%$ sequence divergence. 
Sammlung von Mikroorganismen und Zellkulturen using the HPLC method of Mesbah et al. (1989). The G+C content of the type strain was found to be $42.1 \mathrm{~mol} \%$.

It is clear from the results of this study conducted using a polyphasic taxonomic approach, that the unidentified catalase-negative cocci represent a novel streptococcal species. Phylogenetically, these bacteria isolated from pigs form a distinct subline within the genus Streptococcus and exhibit a loose association with $S$. suis. Sequence analysis of the $\operatorname{sod} A$ and $r p o B$ genes and biochemical profiling also demonstrated that the isolates were distinct from all of the currently recognized streptococcal species. Therefore, on the basis of both phylogenetic and phenotypic criteria it is evident that the unidentified cocci merit classification as a novel species of the genus Streptococcus, for which the name Streptococcus plurextorum sp. nov. is proposed. The two isolates were recovered from different animals, in different farms located in difference provinces of Spain and in different years. Therefore, it is very unlikely that the isolates could have any epidemiological clonality. Tests that are useful in differentiating $S$. plurextorum sp. nov. from the most closely related species (as found in the neighbourjoining phylogenetic tree based on 16S rRNA gene sequences) are shown in Table 1.

\section{Description of Streptococcus plurextorum sp. nov.}

Streptococcus plurextorum (plu.rex.to'rum. L. comp. pl. plures more, several, many; L. pl. n. exta -orum entrails; N.L. gen. pl. n. plurextorum of several internal organs).

Cells are Gram-positive cocci arranged in short chains. Non-motile. Facultatively anaerobic and catalase- and oxidase-negative. Colonies are non-pigmented, circular and $1 \mathrm{~mm}$ in diameter after $24 \mathrm{~h}$ on blood agar and produce an $\alpha$-haemolytic reaction. Growth occurs at $37{ }^{\circ} \mathrm{C}$ but not at 10 or $45^{\circ} \mathrm{C}$. Growth does not occur at $\mathrm{pH} 9.6$ or in broth containing $6.5 \% \mathrm{NaCl}$. Resistant to optochin. Reacts with Lancefield group B antisera. With the API 50 $\mathrm{CH}$ and API Rapid ID 32 Strep kits, cells are able to produce acid from D-lactose, D-glucose, D-fructose, maltose, trehalose, raffinose and sucrose but not from glycerol, erythritol, D-arabinose, L-arabinose, L-xylose, D-adonitol, L-arabitol, D-arabitol, gentiobiose, D-ribose, melibiose, Dmannitol, inositol, dulcitol, melezitose, pullulan, inulin, methyl $\alpha$-D-mannopyranoside, starch, methyl $\beta$-D-glucopyranoside, $\mathrm{N}$-acetylglucosamine, cellobiose, L-rhamnose, L-sorbose, turanose, D-lyxose, xylitol, D-fucose, L-fucose, Dmannose, glycogen, amygdalin, arbutin, sorbitol, 2-ketogluconate, cyclodextrin or tagatose. Delayed acid production occurs for salicin and 5-ketogluconate (API $50 \mathrm{CH}$ ) after 7 days incubation. Acid production from D-galactose and $\mathrm{D}$-xylose is variable (API $50 \mathrm{CH}) . \beta$-Galactosidase, acid phosphatase, leucine arylamidase (API ZYM), $\beta$-glucuronidase, $\alpha$-galactosidase, alanine-phenylalanine-proline arylamidase and glycyl-tryptophan arylamidase (API Rapid ID 32 Strep) are detected. No activity is detected for alkaline phosphatase, $N$-acetyl- $\beta$-glucosaminidase,
naphthol-AS-BI-phosphohydrolase, $\alpha$-glucosidase, $\alpha$-mannosidase, $\alpha$-fucosidase, esterase (C4), ester lipase (C8), lipase (C14), valine arylamidase, cystine arylamidase, trypsin or $\alpha$-chymotrypsin (API ZYM), $\beta$-glucosidase, $\beta$ mannosidase or pyroglutamic acid arylamidase (API Rapid ID 32 Strep). Arginine, hippurate and urea are not hydrolysed (API Rapid ID 32 Strep). Acetoin is not produced (Rapid ID 32 Strep).

The type strain, $1956-02^{\mathrm{T}} \quad\left(=\mathrm{CECT} \quad 7308^{\mathrm{T}}=\right.$ CCUG $52972^{\mathrm{T}}$ ), was isolated from the lungs of a pig with pneumonia. The full habitat is not known. The DNA $\mathrm{G}+\mathrm{C}$ content of the type strain is $42.1 \mathrm{~mol} \%$. Strain 1355 $03(=$ CECT $7307=$ CCUG 52971) is a reference strain.

\section{Acknowledgements}

The authors thank Professor J. P. Euzéby (École Nationale Vétérinaire, Toulouse, France), for advice concerning the Latin epithet, and Juncal Fernández-Garayzábal for her assistance with reviewing the English of the manuscript.

\section{References}

Cashion, P., Holder-Franklin, M. A., McCully, J. \& Franklin, M. (1977). A rapid method for the base ratio determination of bacterial DNA. Anal Biochem 81, 461-466.

Chanter, N. (1997). Streptococci and enterococci as animal pathogens. Soc Appl Bacteriol Symp Ser 26 (Suppl), 100S-109S.

Collins, M. D., Hutson, R. A., Hoyles, L., Falsen, E., Nikolaitchouk, N. \& Foster, G. (2001). Streptococcus ovis sp. nov., isolated from sheep. Int J Syst Evol Microbiol 51, 1147-1150.

Collins, M. D., Hutson, R. A., Falsen, E., Inganas, E. \& Bisgaard, M. (2002). Streptococcus gallinaceus sp. nov., from chickens. Int J Syst Evol Microbiol 52, 1161-1164.

De Ley, J., Cattoir, H. \& Reynaerts, A. (1970). The quantitative measurement of DNA hybridization from renaturation rates. Eur $J$ Biochem 12, 133-142.

Devriese, L. A., Vandamme, P., Collins, M. D., Alvarez, N., Pot, B., Hommez, J., Butaye, P. \& Haesebrouck, F. (1999). Streptococcus pluranimalium sp. nov., from cattle and other animals. Int J Syst Bacteriol 49, 1221-1226.

Drancourt, M., Roux, V., Fournier, P. E. \& Raoult, D. (2004). rpoB gene sequence-based identification of aerobic gram-positive cocci of the genera Streptococcus, Enterococcus, Gemella, Abiotrophia, and Granulicatella. J Clin Microbiol 42, 497-504.

Facklam, R. (2002). What happened to the streptococci: overview of taxonomic and nomenclature changes. Clin Microbiol Rev 15, 613-630.

Facklam, R. \& Elliot, J. A. (1995). Identification, classification, and clinical relevance of catalase-negative, gram-positive cocci, excluding the streptococci and enterococci. Clin Microbiol Rev 8, 479-495.

Guindon, S. \& Gascuel, O. (2003). A simple, fast, and accurate algorithm to estimate large phylogenies by maximum likelihood. Syst Biol 52, 696-704.

Huß, V. A. R., Festl, H. \& Schleifer, K. H. (1983). Studies on the spectrophotometric determination of DNA hybridization from renaturation rates. Syst Appl Microbiol 4, 184-192.

Kilian, M. (1998). Streptococcus and Lactococcus. In Topley \& Wilson's Microbiology and Microbial Infections, vol. 2. Systematic Bacteriology, pp. 633-667. Edited by A. Balows \& B. I. Duerden. London: Arnold. 
Kimura, M. (1980). A simple method for estimating evolutionary rates of base substitutions through comparative studies of nucleotide sequences. J Mol Evol 16, 111-120.

Köhler, W. (2007). The present state of species within the genera Streptococcus and Enterococcus. Int J Med Microbiol 297, 133-150.

Kumar, S., Tamura, K. \& Nei, M. (2004). MEGA3: integrated software for molecular evolutionary genetics analysis and sequence alignment. Brief Bioinform 5, 150-163.

Lawson, P. A., Foster, G., Falsen, E. \& Collins, M. D. (2005a). Streptococcus marimammalium sp. nov., isolated from seals. Int J Syst Evol Microbiol 55, 271-274.

Lawson, P. A., Foster, G. A., Falsen, E., Markopoulos, S. J. \& Collins, M. D. (2005b). Streptococcus castoreus sp. nov., isolated from a beaver (Castor fiber). Int J Syst Evol Microbiol 55, 843-846.

Mesbah, M., Premachandran, U. \& Whitman, W. B. (1989). Precise measurement of the $\mathrm{G}+\mathrm{C}$ content of deoxyribonucleic acid by highperformance liquid chromatography. Int J Syst Bacteriol 39, 159-167.

Okwumabua, O., O'Connor, M. \& Shull, E. (2003). A polymerase chain reaction (PCR) assay specific for Streptococcus suis based on the gene encoding the glutamate dehydrogenase. FEMS Microbiol Lett 218, 79-84.

Page, R. D. M. (1996). TreeView: an application to display phylogenetic trees on personal computers. Comput Appl Biosci 12, 357-358.
Pearson, W. R. (1994). Using the FASTA program to search protein and DNA sequence databases. Methods Mol Biol 24, 307-331.

Poyart, C., Quesne, G., Coulon, S., Berche, P. \& Trieu-Cuot, P. (1998). Identification of streptococci to species level by sequencing the gene encoding the manganese-dependent superoxide dismutase. $J$ Clin Microbiol 36, 41-47.

Rasmussen, S. W. (1995). DNATools, a software package for DNA sequence analysis. Copenhagen: Carlsberg Laboratory.

Ruoff, K. L., Whiley, R. A. \& Beighton, D. (2003). Streptococcus. In Manual of Clinical Microbiology, 8th edn, vol. 1, pp. 409-421. Edited by P. R. Murray, E. J. Baron, J. H. Jorgensen, M. A. Pfaller \& R. H. Yolken. Washington, DC: American Society for Microbiology.

Saitou, N. \& Nei, M. (1987). The neighbor-joining method: a new method for reconstructing phylogenetic trees. Mol Biol Evol 4, 406425.

Vela, A. I., Fernández, E., Lawson, P. A., Latre, M. V., Falsen, E., Domínguez, L., Collins, M. D. \& Fernández-Garayzábal, J. F. (2002). Streptococcus entericus sp. nov., isolated from cattle intestine. Int J Syst Evol Microbiol 52, 665-669.

Wayne, L. G., Brenner, D. J., Colwell, R. R., Grimont, P. A. D., Kandler, O., Krichevsky, M. I., Moore, L. H., Moore, W. E. C., Murray, R. G. E. \& other authors (1987). International Committee on Systematic Bacteriology. Report of the ad hoc committee on reconciliation of approaches to bacterial systematics. Int J Syst Bacteriol 37, 463-464. 